Why did preparers lobby to the IASB's pension accounting proposals?

\author{
Justin Chircop
}

Department of Accounting and Finance, Lancaster University Management School, Lancaster, LA1 4YX, UK. Email: j.chircop1@lancaster.ac.uk

\author{
Paraskevi Vicky Kiosse
}

University of Exeter Business School, Streatham Court, Rennes Drive, Exeter, EX4 4PU, UK. Email: p.kiosse@exeter.ac.uk 


\title{
Why did preparers lobby to the IASB's pension accounting proposals?
}

\section{Justin Chircop and Paraskevi Vicky Kiosse}

\begin{abstract}
This study examines the comment letters submitted by firms to the 2010 Exposure Draft on pensions. This Exposure Draft led to the publication of IAS19(R) which significantly changed pension accounting. In particular, we build on prior literature and examine the characteristics of firms that decided to lobby; we find that signalling as opposed to selfinterest influence the decision to lobby. Further, we examine the preparer's position to two important proposals in the Exposure Draft: the abolition of the corridor approach and the replacement of the expected rate of return on pension plan assets with the discount rate. Overall, we find that submitters are less likely to agree with the abolition of the corridor when they report unrecognized net actuarial losses and that firms are more likely to oppose the replacement of the expected rate of return with the discount rate when the spread between the expected return and the discount rate used when accounting for pensions is large. These results suggest that while signalling drives firm decisions to lobby, self-interest influences how firms lobby.
\end{abstract}

Keywords: Standard setting, defined benefit pension plans, corporate lobbying, IAS 19(R), IASB. 


\section{Introduction}

IAS 19 'Employee Benefits' has been heavily criticised due to the fact that it did not accurately portray the financial position of firms sponsoring defined benefit pension plans. In response to these criticisms, the IASB issued a Discussion Paper in March 2008 'Preliminary views on amendments to IAS 19 employee benefits' and an Exposure Draft 'Defined benefit plans: Proposed amendments to IAS 19' in April 2010, which culminated in the introduction of IAS 19(R) in June 2011. The most important proposed changes in the Exposure Draft focused on two main issues: (a) the abolition of the corridor method when recognizing actuarial gains or losses and (b) the replacement of the expected rate of return on pension plan assets with the discount rate when computing pension expense.

We examine the incentives underlying a firms' decision to submit a comment letter on the 2010 pensions Exposure Draft as well as the factors influencing their decision to agree (oppose) with the proposals to abolish the use of the corridor approach and the replacement of the expected rate of return on pension plan assets with the discount rate. In particular, we hypothesize that signalling and self-interest influence a firm's decision to lobby. We also study whether firms reporting large unrecognized gains or losses are more likely to oppose the abolition of the corridor to avoid the introduction of balance sheet volatility. Moreover, we hypothesize that firms with a large spread between the expected rate of return on plan assets and the discount rate are less likely to support the replacement of the expected rate of return on plan assets with the discount rate as this will likely increase pension expense. We also expect firms with large unrecognized gains or losses to oppose the replacement of the expected rate of return on plan asset with the discount rate given that differences between the discount rate and the actual return on assets will be recognized in other comprehensive income (OCI), which will increase OCI volatility. 
We find that signalling, as captured by pension fund size and the number of shares available for trading positively influences the likelihood of firms submitting a comment letter. When analysing firm responses to the proposal to abolish the corridor, we find that unrealized net actuarial losses are associated with a lower likelihood that submitters agree with the removal of the corridor. Similarly, firms with more dispersed ownership and thus possibly greater information asymmetry between management and its shareholders are also less likely to agree with the removal of the corridor. The analysis examining the likelihood that firms will agree with the replacement of the expected rate of return on plan assets with the discount rate suggests that the larger the spread between the expected rate of return on plan assets and the discount rate the less likely is that firms will agree with the proposal.

Examining the comment letters submitted in the context of the 2010 Exposure Draft on pensions is interesting as the proposed changes have an impact on (a) the calculation and recognition of pension expense and the (b) recognition of actuarial gains or losses for which there was heterogeneity in their treatment under the previous accounting standard IAS 19. In particular, with respect to the first point the proposed changes will have an impact on the expected return on pension plan assets calculation as the proposal suggests replacing the expected rate of return with the discount rate and thus they will have an impact on reported profits. In addition, with respect to the second point, the proposed changes require recognition of unrealized gains or losses in other comprehensive income whereas under IAS 19 firms had a choice to either recognize these in other comprehensive income, in the income statement or keep them off-balance sheet and amortize them if the corridor threshold was triggered; this proposed change will have an impact on balance sheet volatility. Hence, our paper combines the approach adopted by studies which focus on examining lobbying behavior in the context of proposed changes in accounting for items that will be recognized in 
the financial statements (e.g., Francis, 1987; Deakin, 1989; Ramanna, 2008) as well as studies that focus on the recognition of previously disclosed items (Fried, 2012).

This study adds to extant literature studying firm characteristics of companies that participate in the accounting standard-setting due process. In particular, it seeks to add to the relatively limited literature which studies lobbying within the IASB standard-setting context. This study is to our knowledge the first one that attempts to identify the firm characteristics driving the decision to submit a comment letter to the 2010 'Employee Benefits' Exposure Draft, which arguably introduced some of the most significant changes in pension accounting and that seeks to identify the firm characteristics that influence how firms respond to proposals in the Exposure Draft.

The rest of the paper is structured as follows. Section 2 provides an overview of pension accounting standard-setting and Section 3 selectively reviews relevant prior literature and develops the hypotheses to be tested in this study. Section 4 presents the research design, Section 5 discusses the empirical analysis and Section 6 concludes.

\section{Overview of pension accounting standard-setting}

\subsection{Accounting for pensions under IAS 19}

The multitude of options available when recognizing changes in pension assets and liabilities under IAS 19 as well as the flexibility inherent in the choice of the expected rate of return on pension plan assets resulted in lack of transparency and comparability. In particular, firms in different European countries and sometimes firms within the same country opted for different methods when recognizing actuarial gains or losses (Fasshauer, Glaum, \& Street, 2008a, b; Morais, 2010). In addition, the choice of expected rates of return has attracted considerable attention and there is some empirical evidence that managers set this actuarial 
assumption opportunistically both in the UK and the US context (e.g., Li \& Klumpes, 2013; Asthana, 2008; Bergstresser, Desai, \& Rauh, 2006).

Following concerns that the accounting model underlying IAS 19 was inadequate, the International Accounting Standards Board issued a Discussion Paper in March 2008, which was developed in consultation with the IASB's Employee Benefits Working Group, entitled 'Preliminary views on amendments to IAS 19 employee benefits'. The main reasons for issuing the discussion paper rested on both preparers' and users' views that existing pension accounting requirements led to lack of transparency about pension promises (IASB, 2008). Following consideration of the responses to the Discussion Paper, the IASB subsequently issued an Exposure Draft entitled 'Defined benefit plans: Proposed amendments to IAS 19' in April 2010. Table 1 shows the timeline which led to the ultimate publication of IAS 19(R) in June 2011 while the following subsection discusses the main amendments proposed in the Exposure Draft that are relevant to this study.

$<<$ Insert Table 1 around here>>

\subsection{IASB Exposure Draft on pension accounting 'Defined benefit plans: Proposed} amendments to IAS 19'

The Exposure Draft discussed issues relating to recognition and presentation of pension-related numbers, disaggregation and disclosures (IASB, 2010). Our study focuses on two important issues raised in the Exposure Draft concerning recognition and disaggregation. More specifically, consistent with the proposals in the discussion paper, the Exposure Draft proposes the abolition of the corridor and the recognition of the net asset or liability in the balance sheet with the changes in projected benefit obligations and pension plan assets being 
recognized in other comprehensive income. ${ }^{1}$ The Board believed that this is an improvement to pension accounting as the pension-related items to be recognized in the balance sheet and in other comprehensive income will be both relevant and easier for users to understand. In contrast, deferred recognition, which was allowed under IAS 19 resulted in misleading reported numbers as a net pension asset could be recognized in the balance sheet even when the pension plan was in deficit; in addition, gains or losses that relate to previous periods were reported in other comprehensive income (IASB, 2010). Hence, the proposed amendment is purported to provide a more faithful representation of pension obligations. Further, given that the proposed amendments eliminate the options for recognizing actuarial gains or losses under IAS 19, this amendment is believed to enhance comparability of pension-related numbers.

Critics to the proposal noted that until the measurement model is reviewed, the corridor approach should be used on the basis that it reflects the long-term nature of the pension obligation. In addition, opponents noted that some of the changes to the pension liability during the period are not pertinent to the measurement of the long-term liability as actuarial gains or losses in one period may be offset by future actuarial gains or losses. Critics also argued that the ensuing volatility from immediately recognizing actuarial gains or losses would hinder comparability over time and would make the profitability measure more opaque. Moreover, the increased volatility would increase the risk of breaching existing debt covenants and restrict the firm's ability to pay dividends.

The Exposure Draft also proposed the replacement of the expected rate of return on pension plan assets, used in computing the returns on the pension portfolio, with the net interest cost on the net pension asset or liability. The net interest cost would be computed by

\footnotetext{
${ }^{1}$ Under IAS 19, firms had three options when recognizing changes in pension assets and liabilities: (a) they could recognize these in other comprehensive income, (b) in the income statement or (c) keep them off-balance sheet and amortize them only if the corridor threshold (i.e., 10\% of the greater of pension plan assets or pension liabilities) was triggered.
} 
multiplying the net pension asset or liability throughout the period by the interest rate on high quality corporate bonds. Hence, under this approach a company would recognize interest income when the pension plan is in surplus and interest cost when the plan is in deficit. Critics to the proposed approach argued that even though a deficit or surplus would be recognized in the balance sheet, deficits and surpluses have different economic drivers, different explicit or implicit discount rates and are measured on a different basis. While the Board acknowledges the limitation inherent in the proposed approach, using the same discount rate to compute the return on plan assets as that used to calculate the present value of pension obligations is practical as it will not involve subjective judgements about decomposing the return on plan assets into an interest component and a remeasurement component. In addition, the amounts recognized in profit and loss under the proposed approach would better reflect differences between funded and unfunded plans. It should also be noted that differences between the actual return on plan assets and net interest income would not be recognized in profit or loss, but rather in other comprehensive income.

\section{Prior literature and hypotheses development}

The perceived costs and benefits of proposed new accounting standards likely influence the likelihood of various stakeholders' participation in the standard-setting process by submitting a comment letter on the Exposure Draft. This view is consistent with the positive accounting theory developed by Watts \& Zimmerman (1986) and suggests that the benefits of lobbying are influenced by the impact of the accounting proposals on the expected future cash flow of companies. In this respect, when deciding whether or not to submit a comment letter, submitters give consideration to the impact of the proposed changes on reported accounting numbers, the signalling effect the submission of a comment letter might have on various stakeholders, as well as the costs involved in gathering and producing the 
required information. Although there is abundant literature on lobbying of accounting standard setters in the US setting, the literature on the role of lobbying in the IASB standardsetting process is less studied. Given the focus of our study, the discussion of extant prior literature will review studies on lobbying within the context of the IASB standard-setting process and those which examine pension-related standards.

Jorissen, Lybaert, Orens, and Van Der Tas (2010) examine the incentives of various stakeholders to participate in the standard-setting process and find that preparers of accounts as well as accountants and standard setters are more likely to be involved in the standardsetting process when the proposed changes are anticipated to have a significant impact on the accounting numbers reported by companies. They also find that preparers participating in the IASB's due process are typically larger and more profitable. ${ }^{2,3}$ Larson (1997) examines the characteristics of companies that lobby the IASC and sheds light on the extent to which USbased lobbying theories are relevant in the international context. The study finds that lobbying firms (US and firms from other countries) were larger compared to non-lobbying firms in terms of revenue, income and assets. In addition, the majority of lobbying corporations were listed on at least one foreign stock exchange and the majority of non-US lobbying companies traded in the US. Overall, the paper provides support for the applicability of US-based theories in the international context.

\footnotetext{
${ }^{2}$ Using a questionnaire survey, Georgiou (2010) examines the perceptions of and participation in the IASB process of a sample of investment management firms and finds that participation is higher than reflected in the public record of comment letters as many firms express their views through representative organizations such as the Investment Management Association. In addition, the cost of lobbying is found to be the most important factor explaining non-participation in the lobbying process.

${ }^{3}$ Georgiou (2002) examines the reasons why a sample of U.K. firms decided not to make a submission on the ASB's discussion paper on deferred tax. He finds that firm perceptions that their participation would not influence the outcome of the standard-setting process as well as their belief that auditors would represent their position explained their decision not to submit a comment letter. Further, the results are not consistent with the notion that agreement with the proposals in the ASB's discussion paper is more likely to result in a nonresponse than disagreement with the proposals.
} 
Apart from examining the characteristics of firms that decided to lobby, prior literature also examines the incentives influencing the decision to lobby the accounting standard-setting bodies on specific standard-setting issues. In particular within the pensions context, Francis (1987) examines firms' lobbying against the FASB's 1982 proposals on pension accounting which (a) suggested the recognition of the funded status of the pension plan on the balance sheet, (b) constrained flexibility when determining pension expense and (c) gave rise to volatility due to the way that pension expense would be determined. The paper finds that firm size as well as the adverse impact on reported numbers explained the decision to lobby. Kreuze, Langsam, \& Newell (1993) examine the relationship between the proposals included in the Exposure Draft of Statement 106, 'Employer's Accounting for Postretirement Benefits Other Than Pensions' and the final standard and the views expressed in the comment letters submitted to the Exposure Draft. They find that the issues that were partly or wholly modified in the final standard were strongly opposed by the majority of comment letter submitters. In addition, they find that none of the issues with which respondents agreed were modified. More recently, Fried (2012) examines the lobbying behavior of firms in response to SFAS No.158 Exposure Draft on pensions in the US, which proposes the recognition of the (disclosed under the accounting standard prevailing at the time) funded status on the balance sheet. He finds that firms that opposed recognition had large underfunded plans and the magnitude of the balanced sheet adjustments under the proposed changes explained their opposition to the amendments in the Exposure Draft.

Building on prior studies, this study seeks to add to the literature studying lobbying behavior within the IASB standard-setting process. In particular, this paper seeks to fill the lacuna in extant prior literature where even though lobbying to a proposed pension accounting standard has been studied in a US setting, no research has yet explained the drivers of lobbying behavior to a pensions accounting standard within an IASB context. 
Given the different institutional setting and proposed amendments, different firm characteristics to those identified in Francis (1987) and Fried (2012) may have driven submitters to lobby the IASB. Hence, this study contributes to our understanding of lobbying behaviour in an international context. Moreover, in this study we seek to shed light on both the factors that drive submitters to submit a comment letter as well as the factors that influence how submitters lobby to two critical proposals in the 2010 Exposure Draft. Preparers of financial statements constituted one of the most active groups and given the importance of pensions as well as the materiality of pension-related numbers for companies, examining preparer's responses to the proposals is interesting and topical. Even though the use of comment letters is merely one of the ways to lobby, prior research suggests that it is a good proxy for lobbying behavior (Georgiou, 2004) and represents 'one of the most reliable forms of evidence for lobbying studies' (Asekomeh, Russell, \& Tarbert, 2006, p. 57).

We first examine the factors underlying firms' decisions to respond to the 2010 Exposure Draft on pensions. In particular, we shed light on the determinants of firm's decision to submit a comment letter by examining firm and pension-specific characteristics. We attempt to identify whether signalling and / or self-interest drives the decision to submit a comment letter. Signalling is linked to impression management whereby the firm acts to influence stakeholder impressions of the firm; and self-interest is the direct result of the Exposure Draft proposals' perceived influence on reported numbers. In this context, our first set of hypotheses are:

$\mathrm{H}_{1 \mathrm{~A}}$ : The larger the perceived signalling effect of submitting a comment letter, the more likely it is that the firm will submit a comment letter.

$\mathrm{H}_{1 \mathrm{~B}}$ : The larger the perceived cost of implementing the proposals in the Exposure Draft, the more likely it is that the firm will submit a comment letter. 
We also examine the factors underlying firms' decisions to agree or oppose the abolition of the corridor and the replacement of the expected rate of return on pension plan assets with the net interest cost. The proposed abolition of the corridor and the requirement to recognize the net pension asset or liability on the balance sheet and changes in pension assets and liabilities immediately in other comprehensive income will improve comparability and is purported to faithfully represent events and transactions (IASB, 2010). However, the removal of this smoothing mechanism will restrict the deferred recognition of actuarial gains or losses and introduce volatility (Ernst \& Young, 2011). Hence, we would expect firms with unrecognized losses and firms with greater information asymmetry between shareholders and management, ${ }^{4}$ such as firms with more dispersed ownership, to be more likely oppose to the abolition of the corridor which leads to our second set of hypotheses:

$\mathrm{H}_{2 \mathrm{~A}}$ : Firms with large unrecognized losses are more likely to oppose the abolition of the corridor approach.

$\mathrm{H}_{2 \mathrm{~B}}$ : Firms with a high degree of dispersed ownership are more likely to oppose the abolition of the corridor approach.

Further, the proposed abolition of the expected rate of return on pension plan assets and its replacement with the discount rate when computing pension expense implies that the expected return on assets under the proposed change (which is a component of net interest cost) will not reflect the returns expected on the pension portfolio. Indeed, the main reason provided by respondents in the comment letters opposing the utilization of the discount rate is

\footnotetext{
${ }^{4}$ The information asymmetry between shareholders and management is driven by a principal-agent conflict where the principal (shareholders) have less information than the agent (management) as to how the company is being managed. Such conflict enables management to take advantage of the information asymmetry and possibly act to the detriment of shareholders, such as in this case by hiding the true magnitude of unrecognized losses from shareholders.
} 
that it will not reflect the composition of the pension portfolio, which also includes equities and other risky investments. Further, the abolition of the expected rate of return on pension plan assets will constrain manager's ability to use this actuarial assumption in order to manage earnings. Prior literature provides evidence that managers exercise their flexibility over the expected rate of return on plan assets with a view to improving reported earnings ( $\mathrm{Li}$ and Klumpes, 2013; Asthana, 2008; Bergstresser et al., 2006). This leads to the third hypothesis:

$\mathrm{H}_{3}$ : Firms with a wide spread between the expected rate of return and the discount rate are less likely to support the replacement of the expected rate of return on pension plan assets with the discount rate.

\section{Research Design}

\subsection{Sample}

\subsubsection{Submitter group}

Following the publication of the Exposure Draft 'Employee Benefits', 227 comment letters were submitted by various stakeholder groups. ${ }^{5}$ As evident from Figure 1 , the majority of comment letters were submitted by Industrial firms $(28 \%, \mathrm{~N}=63)$, while the lowest number of comment letters were submitted by Academics $(1 \%, \mathrm{~N}=3)$. Equal number of comment letters $(16 \%, \mathrm{~N}=36)$ were submitted by Accounting firms ${ }^{6}$ and Financial institutions. ${ }^{7}$ Two other important stakeholder groups, which submitted comment letters were Actuaries $(15 \%, \mathrm{~N}=33)$ and Accounting standard setters $(7 \%, \mathrm{~N}=17)$.

\footnotetext{
${ }^{5}$ These are publicly available on the IASB's website.

${ }^{6}$ The category 'Accounting' firms also includes professional accounting associations such as the ICAEW.

${ }^{7}$ The category 'Financial institutions' includes both banking and insurance institutions.
} 
$<<$ Insert Figure 1 around here>>

Even though both Financial institutions and Industrials may be classified as preparers we chose to focus our study on Industrials. This is due to the fact that the submission and content of comment letters submitted by Financial institutions may be driven by their client firm characteristics and it is difficult to disentangle the influence of such characteristics from the influence of the particular financial institution's own characteristics. ${ }^{8}$ Hence, our submitter population consists of 63 Industrial firms, two of which are government-owned entities (Hydro-Quebec and Canada Post Corporation) and one firm which is a wholly owned subsidiary of another company, which itself has submitted a comment letter. ${ }^{9}$ Other firms were dropped due to limited data availability, thus our final submitter group consists of 54 firms.

$<<$ Insert Table 2 around here >>

\subsubsection{Control group}

To address our first set of hypotheses and shed light on the firm-level characteristics which may influence the likelihood that a company will submit a comment letter, we augment our submitter group with a control group of firms. Given that we want to identify

\footnotetext{
${ }^{8}$ A similar argument can be made in the case of firms classified as Industrials; however, it is likely that the influence of clients in the comment letters submitted by such firms is negligible. Notwithstanding this, the influence of client characteristics in the choice of whether to submit a comment letter and in the content of such a comment letter will work against us finding a statistically significant association between firm-level characteristics and the submission / content of comment letters.

${ }^{9}$ Telefonos de Mexico S.A.B de C.V. (Telmex) is a wholly owned subsidiary of America Movil and this firm also submitted a comment letter.
} 
the factors influencing the likelihood of submitting a comment letter and that it is ex-ante unclear which characteristics influence the submission of comment letters, we adopt a manyto-one approach when choosing our control group. In this context, we first identify the market in which submitter group firms are listed and then use the Datastream-Market indices constituents for the submitter markets to identify firms for our control group.

The majority of submitter group firms are listed on either the U.S. (36.67\%) or the U.K. (21.67\%) stock markets. These are followed by the German (8.33\%), Swiss (6.67\%), Indian (5\%), Canadian (3.33\%) and French (3.33\%) stock markets. As shown in Table 3, there are 9 other stock markets represented by one submitter firm. Our control group consists of the Datastream Market index ${ }^{10}$ constituents for these markets. This amounts to 3,208 firms, which due to the data requirements discussed in the next section drop to 1,348 firms.

$<<$ Insert Table 3 around here>>

\subsection{Variables}

\subsubsection{Dependent variables}

We test all hypotheses using probit regressions where the dependent variable is a binary variable taking the values of either 1 or 0 . In particular, we created a variable SUB, which takes the value of 1 if the firm has submitted a comment letter and 0 otherwise to test the first set of hypotheses relating to the identification of firm characteristics that distinguish submitters from non-submitters.

\footnotetext{
${ }^{10}$ Datastream-Market indices are calculated on a representative list of stocks for each market, where the number of stocks included covers a minimum of $75-80 \%$ of total market capitalization (Thomson Reuters, 2012).
} 
To test $\mathrm{H}_{2}$ and $\mathrm{H}_{3}$ relating to the factors influencing the comment letter response to questions 1 and 5 of the Exposure Draft, we classify each comment letter according to whether it shows agreement with the relevant proposal in the Exposure Draft. We adopt the following process when classifying comment letters: first, each comment letter was thoroughly read independently by each author and a classification schedule was developed by each author based upon the responses provided to questions 1 and 5 in the Exposure Draft. We classified comment letters as either in agreement or in disagreement with the proposals for the abolition of the corridor and the expected rate of return on pension plan assets proposed in the Exposure Draft. Instances of conditional agreement with a proposal were classified as being in disagreement with the question given that respondents did not completely agree with the proposed changes in these instances. Using only two groupings allows us to simplify the comment letter classification process, while ensuring that we retain sufficient statistical power to conduct the analysis. Subsequently, the classification schedules of each author were compared and the Cohen's Kappa coefficient was computed. As shown in Table 4, for both questions the percentage level of agreement between both authors was over $90 \%$ and the Cohen's Kappa coefficient indicates high level of agreement between the two authors. The small number of comment letters on which there was disagreement on their classification were discussed by the co-authors and a final classification was subsequently agreed upon by both co-authors.

$<<$ Insert Table 4 around here $>>$

Not all 63 submitters answered both questions of interest. In this regard, 53 submitters answered Q1, while 59 submitters answered Q5. Figure 2, shows submitter reaction to the 
two questions of interest. While 58\% of the submitters who answered Q1 agreed with the removal of the corridor approach, the vast majority of submitters answering Q5 (85\%) disagreed with the abolition of the expected rate of return on plan assets. Based on the answers to these two questions, two binary variables, Q1_AGREE and Q5_AGREE taking the value of 1 if respondents agreed with the respective proposal and 0 otherwise, were constructed.

<<Insert Figure 2 around here>>

\subsubsection{Independent variables}

In the first set of hypotheses $\left(\mathrm{H}_{1}\right)$, we posit that there are two dimensions that influence the likelihood that a preparer will submit a comment letter. One dimension is the signalling effect of submitting a comment letter and the second is self-interest. Given that the benefit of managing how a firm is perceived is possibly greater the larger its pension plan and the more dispersed its ownership, we use variables F-SIZE and FREEFLOAT as our two proxies for IMAGE when testing for the signalling effect. F-SIZE is calculated as the logarithmic transformation of the fair values of pension plan assets, while FREEFLOAT is calculated as the percentage number of shares available for trading (i.e., excluding strategic holdings).

The self-interest dimension is the result of the perceived impact of the proposals in the Exposure Draft on the firm. Given that the proposals in Q1 and Q5 were the most controversial and elicited the most debate, we include in our model proxies capturing the degree of impact these proposals would have on firms. Given that as discussed in Section 3, 
firms with wide spreads between the expected rate of return on pension plan assets and the discount rate and firms with unrecognized net actuarial losses are likely to be most affected by the proposals, we include variables SPR and UNR-LOSS in our model. SPR is the difference between expected rate of return on pension plan assets and discount rates, ${ }^{11}$ while UNR-LOSS is a dummy variable which takes the value of 1 if the firm has unrecognized net actuarial losses and 0 otherwise.

We control for a number of factors which may influence our results. These are: SIZE, computed as the logarithmic transformation of total assets; FS, funding status, computed as the fair value of pension plan assets scaled by projected pension benefit obligations; LEV, leverage, calculated as total debt scaled by total shareholders' equity; ROA, return on assets, computed as EBITDA scaled by total assets. When testing the second and third set of hypotheses, we also control for the percentage of pension plan assets invested in equities (EQUITY) given that pension plan asset allocation may influence how firms lobby to the different proposals. Further, we include two dummy variables, IFRS and USGAAP, which take the value of 1 if the firm follows IFRS and USGAAP respectively, and 0 otherwise.

All continuous variables are winsorized at the $1 \%$ level and were computed from data extracted from Datastream for financial year 2009, the year before the publication of the Exposure Draft.

\section{Empirical analysis}

\subsection{Descriptive statistics}

Table 5 shows the descriptive statistics for the independent variables used in the analysis for the whole sample (i.e., including both submitter and control firms). The submitter

\footnotetext{
${ }^{11}$ All results are robust to the scaling of SPR by the expected rate of return.
} 
group consists of larger firms with larger pension plans compared to the control group. The mean (median) F-SIZE for the submitter group is 15.45 (15.75) while the mean (median) for the control group is 12.28 (12.49). Moreover, the submitter group has a larger FREEFLOAT, $0.91(0.94)$ than control group firms, $0.73(0.82)$. Firms in the submitter group have larger SPR and a lower proportion of submitter firms have unrecognized net actuarial losses (UNRLOSS). In particular, the mean (median) SPR for submitter group firms is 1.39 (1.38), the SPR for control group firms is $0.84(0.85)$. Conversely, a larger proportion of control firms (23\%) have unrecognised net actuarial losses than submitter group firms (13\%)

$<<$ Insert Table 5 about here>>

To assess whether the differences between the submitter and control groups are statistically significant, we conduct independent t-tests for difference in means. The results reported in Table 6 suggest that the differences between the two groups for the variables of interest are all statistically significant. In particular, differences in F-SIZE, FREEFLOAT and SPR are statistically significant at the $1 \%$ level, while the difference between the two groups for UNR-LOSS is marginally statistically significant at the $10 \%$ level.

$<<$ Insert Table 6 about here >

Table 7 presents the Pearson correlation matrix for the independent variables. As expected, we find a positive and significant correlation between SIZE and F-SIZE, suggesting 
that larger firms have larger pension plans, and a negative significant correlation between the two dummy variables USGAAP and IFRS, suggesting that most sampled firms use either USGAAP or IFRSs. Interestingly, we find a positive and significant correlation between USGAAP and SPR, possibly driven by U.S. firms in the sample whose pension plan assets tend to be more weighted towards equities. Such firms will use higher expected rates of return on pension plan assets, compared to firms that invest heavily in bonds, thus increasing the spread between expected rates of return and discount rates.

$<<$ Insert Table 7 around here >>

\section{$5.2 \quad$ Testing $\mathrm{H}_{1}$}

To test our first set of hypotheses, we use the following probit model:

$$
\begin{aligned}
\operatorname{Pr}(S U B=1) & =\beta_{0}+\beta_{1} S I Z E+\beta_{2} F-S I Z E+\beta_{3} F R E E F L O A T+\beta_{4} S P R+\beta_{5} U N R \\
& -L O S S+\beta_{6} F S+\beta_{7} L E V+\beta_{8} R O A+\beta_{9} I F R S+\beta_{10} U S G A A P+\varepsilon
\end{aligned}
$$

In line with $\mathrm{H}_{1 \mathrm{~A}}$, which posits that signalling is one of the drivers influencing the likelihood that a firm submits a comment letter, ex-ante we expect to find a statistically significant positive association between our proxies for signalling, F-SIZE and FREEFLOAT, and the probability the firm submits a comment letter. Further, given that as per $\mathrm{H}_{1 \mathrm{~B}}$, self-interest is expected to influence the submission of a comment letter, we hypothesize that SPR and UNR-LOSS are positively related with our dependent variable. 
The results for Model 1, together with the relevant marginal effects are reported in Table 8. Consistent with $\mathrm{H}_{1 \mathrm{~A}}$, we find that signalling is the main factor influencing the submission of a comment letter. In this regard, both proxies for signalling, F-SIZE and FREEFLOAT, are statistically significant in the expected direction, while the proxies for selfinterest (i.e., SPR and UNR-LOSS) are insignificant. This result suggests that the decision about whether to submit a comment letter is primarily driven not by the possible impact the Exposure Draft proposals may have on the company, but from the need of the company to manage stakeholder perceptions. Hence, it is possible that the same firms might regularly submit comment letters in order to signal to their stakeholders that they take an active part in the standard-setting due process.

$<<$ Insert Table 8 around here>>

\section{$5.3 \quad$ Testing $\mathbf{H}_{2}$}

To test the second set of hypotheses, we drop from our sample submitters that did not answer Q1. Q1 was answered by 53 out of the 63 submitters (vide Figure 2); however, the required data is only available for 46 of these firms. Moreover, we amend Model (1), so that our dependent variable is $\operatorname{Pr}\left(\mathrm{Q} 1 \_ \text {AGREE }\right)^{12}$ and include EQUITY, the percentage of pension plan assets allocated to equity, in our vector of control variables.

Table 9 reports the results. In line with $\mathrm{H}_{2 \mathrm{~A}}$, we find that the existence of unrecognized net actuarial losses is statistically significantly associated (at the 5\% level) with a lower probability of submitter agreement with the removal of the corridor approach. This

\footnotetext{
${ }^{12}$ Q1_AGREE takes the value of 1 if the submitter agrees with the proposal (i.e., the abolition of the corridor approach) set out in Q1, and 0 otherwise.
} 
result is driven by the fact that the removal of the corridor approach is likely to be most costly for firms with unrecognized net actuarial losses. With the removal of the corridor approach, such firms will have to recognize any actuarial losses immediately in other comprehensive income, which will give rise to volatility.

We also find a strong positive association significant at the $1 \%$ level between FREEFLOAT and the dependent variable suggesting that firms with more dispersed ownership are less likely to agree with the removal of the corridor approach. Dispersed ownership will more likely result in greater information asymmetry between shareholders and management, thus enabling companies with dispersed ownership to take advantage of the smoothing effect of the corridor approach.

$<<$ Insert Table 9 around here>>

\section{$5.4 \quad$ Testing $\mathrm{H}_{3}$}

To test $\mathrm{H}_{3}$, we drop from our main sample firms that did not answer Q5. There were 59 submitters which answered Q5; however, we drop 9 of these firms from the analysis due to data limitations. Q5 proposed the use of the discount rate instead of the expected rate of return to calculate the expected income from pension plan assets. In this analysis the dependent variable, $\operatorname{Pr}\left(\mathrm{Q} 5 \_\right.$AGREE), takes the value of 1 if a submitter agrees with the removal of the expected rate of return and 0 otherwise. Table 10 reports the results. Consistent with $\mathrm{H}_{3}$, we find that SPR is marginally negatively associated with the probability of agreement with Q5. Thus, submitters with wider spreads between the expected rate of 
return on pension plan assets and discount rates are less likely to agree with the replacement of the expected rate of return with the discount rate.

$<<$ Insert Table 10 around here >>

\section{Concluding remarks}

We examine the characteristics of firms that submitted comment letters to the 2010 Exposure Draft on pensions. In addition, we examine the incentives underlying firm decisions to oppose two controversial proposals in the Exposure Draft: the abolition of the corridor method when recognizing actuarial gains or losses and the replacement of the expected rate of return on plan assets with the discount rate when computing pension expense. We find that signalling as captured by both pension plan size and percentage of shares available for trading influence the decision to lobby. When analysing firm's positions to the abolition of the corridor approach, we find that firms with unrecognized net actuarial losses are less likely to agree with the removal of the corridor. Further, when analysing firm responses to the replacement of the expected rate of return on plan assets with the discount rate, we find that firms with wider spreads between the expected rate of return on plan assets and the discount rate are less likely to agree with the proposal.

Using comment letters to examine the hypothesized relationships is appropriate given that they reflect the views of the preparers who chose to submit a comment letter. However, we acknowledge that our study suffers from the sampling issues that are relevant to other studies in this area, in that we are only able to analyse the views of companies that responded to the Exposure Draft (Asekomeh et al., 2006). Overall, the results suggest that the impact of 
the proposed changes on reported numbers, such as increased volatility and decrease in earnings, influences preparer's position to these two important proposals in the pensions Exposure Draft. Future research can examine the impact of the revised accounting standard IAS 19(R) (IASB, 2011), which abolished the corridor and replaced the expected rate of return with the discount rate, on reported numbers as well as market reactions. 


\section{Appendix}

In this study, we examine the firm characteristics which motivate submitters to lobby by submitting a comment letter and the firm characteristics which drive their responses to two important proposals in the 2010 'Employee Benefits' Exposure Draft. The two questions studied were questions 1 and 5 in the Exposure Draft.

\section{Question 1}

Question 1 related to recognition: "The Exposure Draft proposes that entities should recognize all changes in the present value of the defined benefit obligation and in the fair value of plan assets when they occur (Paragraphs 54, 61 and BC9-BC12). Do you agree? Why or why not?"

\section{Question 5}

Question 5 related to defining the finance cost component: "The Exposure Draft proposes that the finance cost component should comprise net interest on the net defined benefit liability (asset) determined by applying the discount rate specified in paragraph 78 to the net defined benefit liability (asset). As a consequence, it eliminates from IAS 19 the requirement to present an expected return on plan assets in profit or loss. Should net interest on the net defined benefit liability (asset) be determined by applying the discount rate specified in paragraph 78 to the net defined benefit liability (asset)? Why or why not? If not, how would you define the finance cost component and why?" (Paragraphs 7, 119B, 119C and BC23$\mathrm{BC} 32)$. 


\section{References}

Asekomeh, A. O., Russell, A., \& Tarbert, H. (2006). A critical analysis of the use of accounting standards' comment letters as lobbing tools by extractive industry firms. Petroleum Accounting and Financial Management Journal, 25(3), 55-76.

Asthana, S. (2008). Earnings management, expected returns on pension assets, and resource allocation decisions. Journal of Pension Economics and Finance, 7(2), 199-220.

Bergstresser, D., Desai, M., \& Rauh, J. (2006). Earnings manipulation, pension assumptions, and managerial investment decisions. Quarterly Journal of Economics, 121(1), 157-195.

Deakin, E. B. (1989). Rational economic behaviour and lobbying on accounting issues: Evidence from the oil and gas industry. The Accounting Review, 64(1), 137-151.

Ernst \& Young, (2011). Implementing the 2011 revisions to employee benefits.

Fasshauer, J. D., Glaum, M., \& Street, D. L. (2008a). Adoption of IAS 19 by Europe's premier listed companies: Corridor approach versus full recognition, Summary of an ACCA research monograph. Journal of International Accounting, Auditing and Taxation, 17, 113-122.

Fasshauer, J. D., Glaum, M., \& Street, D. (2008b). Adoption of IAS 19 by Europe's premier listed companies: Corridor approach versus full recognition (Research report 100). London: ACCA.

Francis, J. R. (1987). Lobbying against proposed accounting standards: The case of employer's pension accounting. Journal of Accounting and Public Policy, 6, 35-57.

Fried, A. N. (2012). Disclosure versus recognition: Evidence from lobbying behaviour in response to SFAS No. 158. Research in Accounting Regulation, 24(1), 25-32. 
Georgiou, G. (2002). Corporate non-participation in the ASB standard-setting process. The European Accounting Review, 11(4), 699-722.

Georgiou, G. (2004). Corporate lobbying on accounting standards: Methods, timing and perceived effectiveness. Abacus, 40(2), 219-237.

Georgiou, G. (2010). The IASB standard-setting process: Participation and perceptions of financial statement users. The British Accounting Review, 42, 103-118.

International Accounting Standards Board (IASB), (2008). Discussion paper: Preliminary views on amendments to IAS 19 employee benefits. London: IASB.

International Accounting Standards Board (IASB), (2010). Exposure draft: Defined benefit plans, proposed amendments to IAS 19. London: IASB.

International Accounting Standards Board (IASB), (2011). IAS 19 - Employee benefits (revised). London: IASB.

Jorissen, A., Lybaert, N., Orens, R., \& Van Der Tas, L. (2010). Formal participation in the IASB's due process of standard setting: A multi-issue/multi-period analysis. European Accounting Review, 21(4), 1-37.

Kreuze, J. G., Langsam, S. A., \& Newell, G. E. (1993). Accounting for nonpension postretirement benefits: Analysis of lobbying activities. American Journal of Business, $8(1), 25-32$.

Larson, R. K. (1997). Corporate lobbying of the International Accounting Standards Committee. Journal of International Financial Management and Accounting, 8(3), 175203. 
Li, Y., \& Klumpes, P. (2013). Determinants of expected rate of return on pension assets: Evidence from the UK. Accounting and Business Research, 43(1), 3-30.

Morais, A.I. (2010). Actuarial gains and losses: the choice of the accounting method. Accounting in Europe, 5(2), 127-139.

Ramanna, K. (2008). The implications of unverifiable fair-value accounting: Evidence from the political economy of goodwill accounting. Journal of Accounting and Economics, 45, 253-281.

Thomson Reuters (2012). Datastream Global Equity Indices User Guide V.5 [online] Available at: http://extranet.datastream.com/data/Equity\%20indices/documents/Datastream GlobalEquityIndicesUGissue05.doc Accessed on: 20/01/2015.

Watts, R. L., \& Zimmerman, J. L. (1986). Positive accounting theory. N: Prentice-Hall. 


\section{Figure 1}

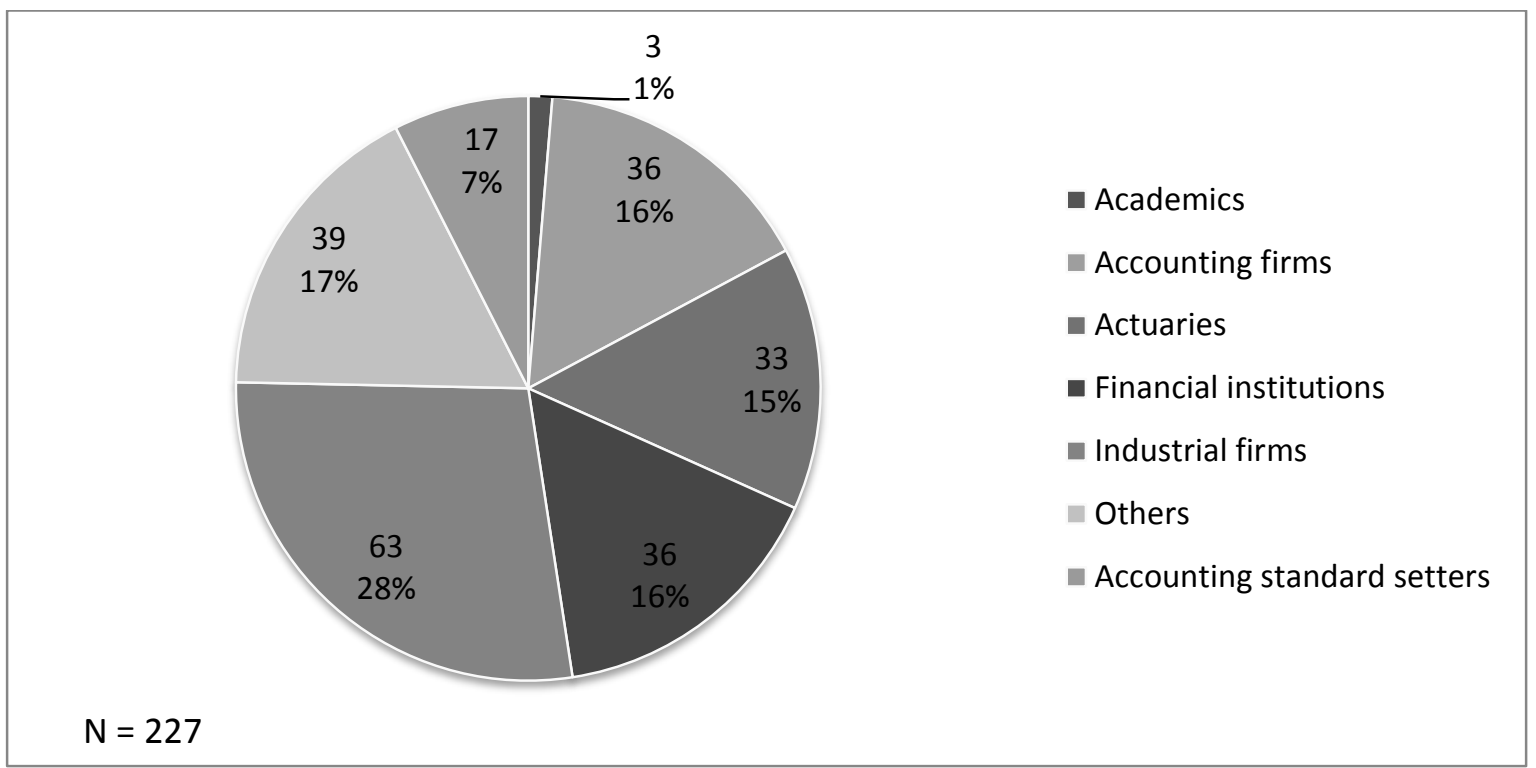

Figure 1: This figure presents the distribution of comment letters by stakeholder groups. 


\section{Figure 2}

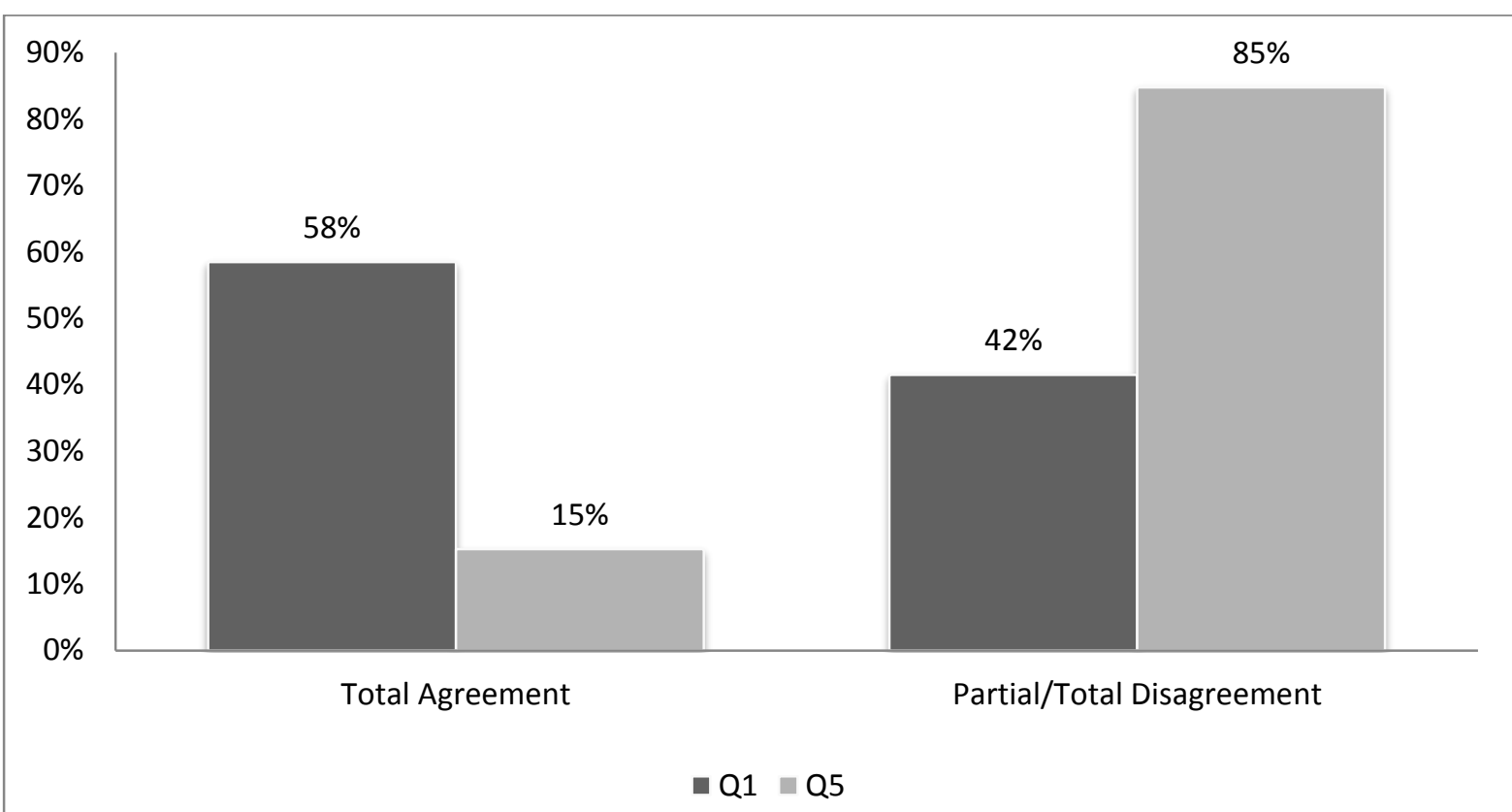

Figure 2: This figure presents a bar chart illustrating percentage agreement with the proposals set out in questions $1(\mathrm{Q} 1)$ and $5(\mathrm{Q} 5)$ of the Exposure Draft. Not all 63 preparer submitters answered all questions set out in the Exposure Draft. Q1 was answered by 53 submitters, while Q5 was answered by 59 submitters. 
Table 1

\begin{tabular}{|c|c|}
\hline Date & Details \\
\hline 01 March 2008 & $\begin{array}{l}\text { Discussion paper 'Preliminary views on amendments to IAS } 19 \text { Employee } \\
\text { Benefits' published. }\end{array}$ \\
\hline 29 April 2010 & $\begin{array}{l}\text { Exposure Draft ED/2010/3 'Defined Benefit Plans - Proposed amendments to } \\
\text { IAS 19' published. }\end{array}$ \\
\hline 6 September 2010 & Deadline of Exposure Draft Defined ED/2010/3 comment period. \\
\hline 16 June 2011 & IAS19R ‘Employee benefits’ issued. \\
\hline 1 January 2013 & Effective date of IAS19R 'Employee benefits' \\
\hline
\end{tabular}

Table 1: List of key dates in the publication of IAS 19(R) 'Employee benefits.' 
Table 2

\begin{tabular}{ll} 
Company name & ISIN code \\
\hline AIR FRANCE-KLM & FR0000031122 \\
ALCOA INCORPORATED & US0138171014 \\
ALTRIA GROUP INCO. & US02209S1033 \\
AMERICA MOVIL SAB DE CV & MXP001691015 \\
ANGLO AMERICAN PLC. & GB00B1XZS820 \\
ASTRAZENECA PLC. & GB0009895292 \\
BALFOUR BEATTY PLC. & GB0000961622 \\
BASF SE & DE000BASF111 \\
BAYER AG & DE000BAY0017 \\
BP PLC. & GB0007980591 \\
BRITISH AMER.TOB.PLC. & GB0002875804 \\
BT GROUP PLC. & GB0030913577 \\
CHEVRON CORP. & US1667641005 \\
CIGNA CORP. & US1255091092 \\
CONSTELLATION BNS.INCO. & US21036P1084 \\
DARTY PLC. & GB0033040113 \\
DEUTSCHE POST AG & DE0005552004 \\
E ON AG & DE000ENAG999 \\
ELI LILLY \& CO. & US5324571083 \\
ENTERGY CORP. & US29364G1031 \\
EXXON MOBIL CORP. & US30231G1022 \\
FIRSTENERGY CORP. & US3379321074 \\
FLETCHER BUILDING LTD. & NZFBUE0001S0 \\
FORD MOTOR CO. & US3453708600 \\
HOLCIM LTD. & CH0012214059 \\
INFOSYS LTD. & INE009A01021 \\
INTL.BUS.MCHS.CORP. & US4592001014 \\
INTL.CONS.AIRL.GROUP SA & ES0177542018 \\
JARDINE MTSN.HDG.LTD. & BMG507361001 \\
KONINKLIJKE DSM & NL0000009827 \\
LARSEN \& TOUBRO LTD. & INE018A01030 \\
&
\end{tabular}

\begin{tabular}{ll} 
Company name & ISIN code \\
\hline NESTLE SA & CH0038863350 \\
NORSK HYDRO ASA & NO0005052605 \\
PEPSICO INCO. & US7134481081 \\
PFIZER INCO. & US7170811035 \\
PPL CORP. & US69351T1060 \\
PROGRESS EN.RES.CORP. & CA74326Y1079 \\
RAYONIER INCO. & US7549071030 \\
RAYTHEON CO. & US7551115071 \\
REED ELSEVIER PLC. & GB00B2B0DG97 \\
ROCHE HOLDING AG & CH0012032048 \\
ROYAL DUTCH SHELL & GB00B03MLX29 \\
SANOFI & FR0000120578 \\
SAPPI LTD. & ZAE000006284 \\
SIEMENS AG & DE0007236101 \\
SKF AB & SE0000108227 \\
STAGECOACH GROUP PLC. & GB00B6YTLS95 \\
SYNGENTA AG & CH0011037469 \\
TATA STEEL LTD. & INE081A01012 \\
TELSTRA CORPORATION LTD. & AU000000TLS2 \\
TESCO PLC. & GB0008847096 \\
THE GOODYEAR TI.\& RUB.CO & US3825501014 \\
THE MCGRAW-HILL COS.INCO & US5806451093 \\
TRANSCAN.CORP. & CA89353D1078 \\
UNILEVER PLC. & GB00B10RZP78 \\
UNITED TECHS.CORP. & US9130171096 \\
URS CORP. & US9032361076 \\
US.STEEL CORP. & US9129091081 \\
VERIZON COMMUNICATIONS & US92343V1044 \\
TELEFONOS DE MEXICO S.A.B DE C.V. & $\mathrm{n} / \mathrm{a}$ \\
HYDRO-QUEBEC & $\mathrm{n} / \mathrm{a}$ \\
CANADA POST CORPORATION & $\mathrm{n} / \mathrm{a}$ \\
& \\
\hline &
\end{tabular}


Table 2: This table presents details of the constituents of the Industrial submitter group. Telefonos de Mexico S.A.B de C.V. (Telmex) is a wholly owned subsidiary of America Movil, a firm that also submitted a comment letter, while both Hydro-Quebec and Canada Post Corporation are government-owned entities. 
Table 3

\begin{tabular}{lccc} 
Market & Freq. & Percent & Cum. \\
\hline AUSTRALIA & 1 & 1.67 & 1.67 \\
CANADA & 2 & 3.33 & 5 \\
FRANCE & 2 & 3.33 & 8.33 \\
GERMANY & 5 & 8.33 & 16.67 \\
HONG KONG & 1 & 1.67 & 18.33 \\
INDIA & 3 & 5.00 & 23.33 \\
MEXICO & 1 & 1.67 & 25 \\
NETHERLANDS & 1 & 1.67 & 26.67 \\
NEW ZEALAND & 1 & 1.67 & 28.33 \\
NORWAY & 1 & 1.67 & 30 \\
SOUTH AFRICA & 1 & 1.67 & 31.67 \\
SPAIN & 1 & 1.67 & 33.33 \\
SWEDEN & 1 & 1.67 & 35 \\
SWITZERLAND & 4 & 6.67 & 41.67 \\
UNITED KINGDOM & 13 & 21.67 & 63.33 \\
UNITED STATES & 22 & 36.67 & 100 \\
\hline Total & 60 & 100 & \\
\hline Table 3: This table presents the countries where submitter firms are listed.
\end{tabular}


Table 4

\begin{tabular}{c|cc} 
Question No. & $\begin{array}{c}\text { Percent } \\
\text { Agreement }\end{array}$ & Cohen's Kappa \\
\hline 1 & 90.48 & 0.85 \\
5 & 98.41 & 0.96 \\
\hline
\end{tabular}

Table 4: This table presents the percentage level of agreement and the Cohen's Kappa coefficient for the inter-rater agreement achieved by the two coauthors in the classification of submitter comment letters. Comment letters were classified as either in agreement to or in disagreement with the proposals set out in the Exposure Draft questions examined in this study. 
Table 5

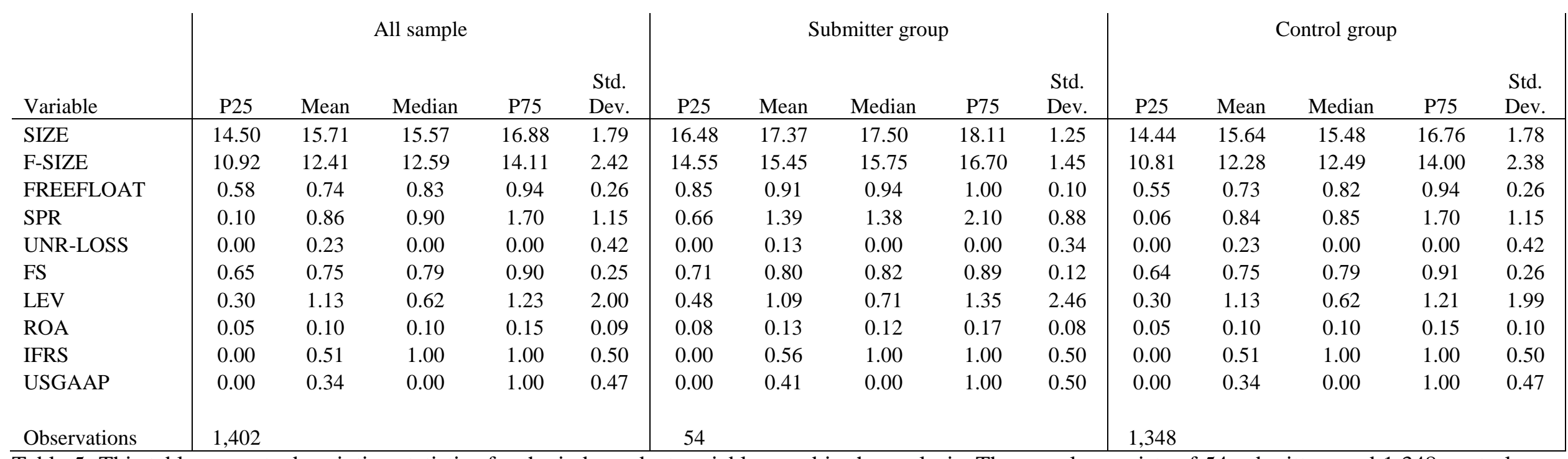

Table 5: This table presents descriptive statistics for the independent variables used in the analysis. The sample consists of 54 submitters and 1,348 control group firms, for which the data required to compute the independent variables was available. SIZE is calculated as the logarithmic transformation of total assets; F-SIZE is the logarithmic transformation of the fair value of pension plan assets; FREEFLOAT is calculated as the percentage number of shares available for trading after excluding strategic ownership; SPR is the difference between the long-term expected rate of return on pension plan assets and pension plan discount rate; UNRLOSS is a dummy variable which takes the value of 1 if the firm has unrealized net pension actuarial losses and 0 otherwise; FS is pension plan funding status calculated as the fair value of pension plan assets scaled by pension projected benefit obligations; LEV is calculated as total debt scaled by total shareholders' equity and ROA, return on assets, computed as EBITDA scaled by total assets; and two dummy variables - IFRS and USGAAP - which take the value of 1 if the preparer follows IFRS or USGAAP respectively, and 0 otherwise. All continuous variables are winsorized at the $1 \%$ level. 
Table 6

\begin{tabular}{l|cccc}
\multirow{2}{*}{ Variable } & \multicolumn{3}{|c}{ Mean } & \\
\cline { 2 - 3 } & $\begin{array}{c}\text { Submitter } \\
\text { group }\end{array}$ & $\begin{array}{c}\text { Control } \\
\text { group }\end{array}$ & Difference & p-value \\
\hline SIZE & 17.37 & 15.64 & 1.73 & 0.0000 \\
F-SIZE & 15.45 & 12.28 & 3.17 & 0.0000 \\
FREEFLOAT & 0.91 & 0.73 & 0.18 & 0.0000 \\
SPR & 1.39 & 0.84 & 0.55 & 0.0015 \\
UNR-LOSS & 0.13 & 0.23 & -0.10 & 0.0860 \\
FS & 0.80 & 0.75 & 0.05 & 0.1651 \\
LEV & 1.09 & 1.13 & -0.04 & 0.8878 \\
ROA & 0.13 & 0.10 & 0.02 & 0.0856 \\
IFRS & 0.56 & 0.51 & 0.05 & 0.5016 \\
USGAAP & 0.41 & 0.34 & 0.07 & 0.2991 \\
& & & & \\
Observations & 54 & 1,348 & & \\
\hline
\end{tabular}

Table 6: This table presents the results for independent $t$-tests for difference in mean between the submitter and control groups. The $\mathrm{p}$-values are for two-side t-tests. All variables are as defined in Table 5. 
Table 7

\begin{tabular}{|c|c|c|c|c|c|c|c|c|c|c|}
\hline & SIZE & F-SIZE & FREEFLOAT & SPR & $\begin{array}{l}\text { UNR- } \\
\text { LOSS }\end{array}$ & FS & LEV & ROA & IFRS & USGAAP \\
\hline SIZE & 1 & & & & & & & & & \\
\hline \multirow[t]{2}{*}{ F-SIZE } & 0.6621 & 1 & & & & & & & & \\
\hline & 0.0000 & & & & & & & & & \\
\hline \multirow[t]{2}{*}{ FREEFLOAT } & 0.2393 & 0.3576 & 1 & & & & & & & \\
\hline & 0.0000 & 0.0000 & & & & & & & & \\
\hline \multirow[t]{2}{*}{ SPR } & 0.2316 & 0.3501 & 0.2333 & 1 & & & & & & \\
\hline & 0.0000 & 0.0000 & 0.0000 & & & & & & & \\
\hline \multirow[t]{2}{*}{ UNR-LOSS } & -0.0552 & -0.0485 & -0.1481 & -0.1430 & 1 & & & & & \\
\hline & 0.0388 & 0.0694 & 0.0000 & 0.0000 & & & & & & \\
\hline \multirow[t]{2}{*}{ FS } & 0.0783 & 0.3721 & 0.1577 & 0.1506 & -0.0984 & 1 & & & & \\
\hline & 0.0034 & 0.0000 & 0.0000 & 0.0000 & 0.0002 & & & & & \\
\hline \multirow[t]{2}{*}{ LEV } & 0.2677 & 0.1307 & -0.0229 & -0.0037 & 0.0061 & 0.0109 & 1 & & & \\
\hline & 0.0000 & 0.0000 & 0.3914 & 0.8903 & 0.8183 & 0.6823 & & & & \\
\hline \multirow[t]{2}{*}{ ROA } & -0.2475 & -0.0881 & -0.0410 & 0.0691 & -0.0229 & -0.0073 & -0.1552 & 1 & & \\
\hline & 0.0000 & 0.0010 & 0.1248 & 0.0097 & 0.3908 & 0.7836 & 0.0000 & & & \\
\hline \multirow[t]{2}{*}{ IFRS } & -0.1130 & -0.0454 & -0.1389 & -0.3913 & 0.2002 & -0.1001 & 0.0452 & -0.1019 & 1 & \\
\hline & 0.0000 & 0.0891 & 0.0000 & 0.0000 & 0.0000 & 0.0002 & 0.0905 & 0.0001 & & \\
\hline \multirow[t]{2}{*}{ USGAAP } & 0.2203 & 0.2735 & 0.3195 & 0.5175 & -0.3310 & 0.0653 & -0.0321 & 0.0340 & -0.7360 & 1 \\
\hline & 0.0000 & 0.0000 & 0.0000 & 0.0000 & 0.0000 & 0.0145 & 0.2295 & 0.2031 & 0.0000 & \\
\hline
\end{tabular}

Table 7: This table presents the Pearson correlation matrix for the entire sample. The sample of 1,402 firms consists of 54 submitters and 1,348 control group firms, for which the data required to compute the independent variables, are available. All variables are as defined in Table 5. 
Table 8

\begin{tabular}{l|cccc} 
& \multicolumn{4}{|c}{ SUB } \\
Variable & Coefficient & Z-statistic & $\begin{array}{c}\text { Marginal } \\
\text { effects }\end{array}$ \\
\hline SIZE & -0.05 & & -0.64 & 0.00 \\
F-SIZE & 0.48 & $* * *$ & 5.95 & 0.03 \\
FREEFLOAT & 1.22 & $* *$ & 2.3 & 0.07 \\
SPR & 0.15 & & 1.4 & 0.01 \\
UNR-LOSS & -0.32 & -1.34 & -0.02 \\
FS & -0.82 & & -1.58 & -0.05 \\
LEV & -0.04 & -1.17 & 0.00 \\
ROA & 1.82 & $*$ & 1.77 & 0.11 \\
IFRS & -0.09 & -0.23 & -0.01 \\
USGAAP & -0.55 & -1.38 & -0.03 \\
Constant & -8.05 & $* * *$ & -7.33 & \\
& & & & \\
Observations & 1,402 & & \\
Pseudo R-squared & 0.315 & & & \\
\hline
\end{tabular}

Table 8: This table presents the results for the probit model testing $\mathrm{H}_{1}$. The sample consists of 1,402 firms: 54 submitters and 1,348 control group firms, for which the data required to compute the independent variables are available. SUB is a dummy variable which takes the value of 1 if the firm submitted a comment letter, and 0 otherwise. Marginal effects are the average partial effect of the explanatory variable on the probability of observing a 1 in the dependent variable. All variables are as defined in Table 5. $* * *$ and $* * *$ refer to $10 \%$, $5 \%$ and $1 \%$ level of significance respectively. 
Table 9

\begin{tabular}{l|cccr} 
& \multicolumn{4}{|c}{ Pr (Q1_AGREE) } \\
Variable & Coefficient & Z-statistic & $\begin{array}{c}\text { Marginal } \\
\text { effects }\end{array}$ \\
\hline SIZE & 0.47 & & 0.93 & 0.09 \\
F-SIZE & -0.43 & & -0.94 & -0.08 \\
FREEFLOAT & 15.64 & $* * *$ & -2.76 & -2.82 \\
SPR & 0.12 & & 0.23 & -1.11 \\
UNR-LOSS & -2.14 & $* *$ & -2.15 & 1.62 \\
FS & -6.17 & $*$ & -1.81 & 0.02 \\
LEV & 0.12 & & 0.65 & 0.09 \\
ROA & 8.97 & & 1.46 & 0.02 \\
EQUITY & 0.52 & & 0.19 & -0.37 \\
IFRS & 5.09 & $*$ & 1.77 & 0.70 \\
USGAAP & 1.97 & & 0.73 & 0.22 \\
Constant & 13.22 & $* *$ & 2.12 &
\end{tabular}

Observations $\quad 46$

Pseudo R-squared $\quad 0.51$

Table 9: This table presents the results for the probit model testing $\mathrm{H}_{2}$. The sample consists of the 46 submitters that answered Q1 of the Exposure Draft and for which data are available. Q1_AGRRE is a dummy variable, which takes the value of 1 if the firm agreed with the proposal set in Q1, and 0 otherwise. EQUITY is the percentage of pension plan assets allocated to equities. All other independent variables are defined in Table 5. Marginal effects are the average partial effect of the explanatory variable on the probability of observing a 1 in the dependent variable. ${ }^{*}, * *$ and $* * *$ refer to $10 \%$, $5 \%$ and $1 \%$ level of significance respectively. 
Table 10

\begin{tabular}{l|cccr} 
& \multicolumn{3}{|c}{ Q5_AGREE } \\
Variable & Coefficient & Z-statistic & $\begin{array}{c}\text { Marginal } \\
\text { effects }\end{array}$ \\
\hline SIZE & 0.75 & $*$ & 1.66 & 0.13 \\
F-SIZE & -0.70 & $*$ & -1.83 & -0.12 \\
FREEFLOAT & -2.20 & & -0.58 & -0.39 \\
SPR & -0.93 & $*$ & -1.83 & 0.04 \\
UNR_LOSS & -1.27 & & -1.06 & 1.49 \\
FS & 0.22 & & 0.1 & 0.00 \\
LEV & -0.02 & & -0.13 & -0.68 \\
ROA & 8.28 & & 1.42 & -0.17 \\
EQUITY & -3.80 & -1.05 & -0.15 \\
IFRS & 1.23 & 0.73 & 0.20 \\
USGAAP & 2.05 & 0.94 & 0.37 \\
Constant & -1.20 & -0.25 &
\end{tabular}

Observations $\quad 50$

Pseudo R-squared $\quad 0.264$

Table 10: This table presents the results for the probit model testing $\mathrm{H}_{3}$. The sample consists of the 50 submitters that answered Q5 of the Exposure Draft and for which data are available. Q5_AGREE is a dummy variable, which takes the value of 1 if the firm agreed with the proposal set in Q5, and 0 otherwise. EQUITY is the percentage of pension plan assets allocated to equities. All other independent variables are as defined in Table 5. Marginal effects is the average partial effect of the explanatory variable on the probability of observing a 1 in the dependent variable.*,** and $* * *$ refer to $10 \%, 5 \%$ and $1 \%$ level of significance respectively. 